\title{
Determining the Levels of How Families Shape Children's Engagement with Science: A Scale Development Study*
}

\section{Ailelerin Çocuklarını Bilime Yönlendirme Düzeylerini Belirleme: Ölçek Geliştirme Çalışması}

\author{
Emine BAL ${ }^{* *}$ (iD)
}

\author{
Gökhan KAYA***
}

Received: 09 June 2021

Research Article

Accepted: 16 December 2021

ABSTRACT: This study aims to develop a scale that can be used to determine the levels of how families shape children's engagement with science. The study was conducted in the basic research design. The data collection was carried out in two stages. In the first stage, the data obtained from the scale applied to 324 people were subjected to exploratory factor analysis. In the second stage, data from 181 people were used for confirmatory factor analysis. As a result of the EFA, it was found that the factor loads ranged from .521 to .893 , the Kaiser-Meyer-Olkin value was .866 , the total variance explained was $62.254 \%$, and the Cronbach's alpha value was .907. As a result of the CFA, however, it was found that the $X^{2} / d f$ value was 2, and the RMSEA value was .079. Thus, a 5-point, 3-factor Likert type scale, consisting of 18 items, was obtained with validity and reliability according to the analysis results. The factors involved in the scale were called "Practical Applications (Activities and Experiments)", "Introduction to Science" and "Building Scientific Foundations". With the developed scale, it is believed that researchers in the field can determine the level of orientation of children of families with different demographics and children of different age groups to science.

Keywords: Science, family orientation, engagement with science, family science.

ÖZ: Bu çalışmanın amacı, ailelerin çocuklarını bilime yönlendirme düzeylerini belirlemek için kullanılabilecek bir ölçek geliştirmektir. Çalışma temel araştırma niteliğinde yürütülmüştür. Amaç doğrultusunda ilk olarak ilgili alan yazın taranarak madde havuzu oluşturulmuştur. Oluşturulan madde havuzu uzman görüşüne sunulmuş ve daha sonra ölçeğin pilot uygulaması yapılmıştır. Uygulama kapsamında toplam 505 ebeveyn araştırmanın çalışma grubunu oluşturmuştur. Uygulama iki aşamada yürütülmüştür. Birinci aşamada 324 kişiye uygulanan ölçekten elde edilen veriler açımlayıcı faktör analizine tabi tutulmuştur. İkinci aşamada ise 181 kişiye uygulanan ölçekten elde edilen veriler doğrulayıcı faktör analizi için kullanılmıştır. Açımlayıcı faktör analizi sonucu faktör yüklerinin .521 ile .893 arasında değiştiği, Kaiser-Meyer-Olkin değerinin .866, açıklanan toplam varyansın \%62.254 ve Cronbach's Alpha değerinin ise .907 olduğu bulunmuştur. Doğrulayıcı faktör analizi sonucu ise $X^{2} / S d$ değerinin 2 olduğu, RMSEA değerinin .079 olduğu bulunmuştur. Yapılan araştırma doğrultusunda elde edilen verilerin analiz sonuçlarına göre araştırmacılar tarafından geçerliği ve güvenirliği sağlanmış 18 maddeden oluşan 5'li likert tipinde 3 faktörlü bir ölçek elde edilmiştir. Ölçekte yer alan faktörler "Pratik Uygulamalar (Etkinlik ve Deney)", "Bilimle Tanıştırma" ve "Bilimsel Temel Oluşturma" olarak adlandırılmıştır. Geliştirilen ölçek ile alandaki araştırmacıların, farklı demografik özelliklere sahip ve farklı yaş gruplarında çocuğu olan ailelerin çocuklarını bilime yönlendirme düzeylerini belirleyebileceği düşünülmektedir.

Anahtar kelimeler: Bilim, aile yönlendirmesi, bilime teşvik, aile bilimi.

\footnotetext{
* The summary of the study was presented as an oral presentation at the 14th National Science and Mathematics Education Congress [14. Ulusal Fen Bilimleri ve Matematik Eğitimi Kongresi (UFBMEK2021)].

** Postgraduate Student, Kastamonu University, Faculty of Education, Turkey, oguzemine97@gmail.com, https://orcid.org/0000-0002-9740-2078

*** Corresponding Author: Asst. Prof. Dr., Kastamonu University, Faculty of Education, Turkey, gkaya@kastamonu.edu.tr, https://orcid.org/0000-0003-4044-9243
}

\section{Citation Information}

Bal, E., \& Kaya, G. (2022). Determining the levels of how families shape children's engagement with science: A scale development study. Kuramsal Eğitimbilim Dergisi [Journal of Theoretical Educational Science], 15(1), 169190. 
Considering the past and present developments and practices, science is at the forefront and essential in every field and period. Science is one way of learning and acquiring knowledge and consists of beliefs and values in acquiring and developing scientific knowledge (Güler \& Akman, 2006). There is a great need for science for new developments and implementations as it has been so far. Science is a trigger for further production and change in all areas. As with everything else, it is up to today's children to use science correctly and carry it into the future and continuously improve (Kunt, 2015).

In children, the perception of science and the formation of concepts related to science begins in preschool, as in all other areas (Ayvacı et al., 2016). The first interaction with science and the learning of scientific concepts first starts in infancy, in which children explore their surroundings by observations and learn to think (Akman et al., 2003). After infancy, young children learn about science by appealing in the investigation, inspection and wonder, characteristic of early childhood (National Research Council [NRC], 2007, 2012). Early childhood can be considered the best time for children to be introduced to science because their learning processes have also begun with their curiosity about the world (Kefi et al., 2013; NRC, 2007). Studies also show that children's involvement with science at an early age is a factor that positively increases science performances in later years of education (Morgan et al., 2016). For all these reasons, efforts to increase success in science and close the gaps in science achievement among children in the future should start in childhood and include their parents' education. Because one of the ways children learn science is to observe and imitate the scientific activities of adults (Raynal et al., 2021). Increasing the ability of parents to develop children's scientific dispositions helps children build actual experiences of science (NRC, 2007, 2012); these actual experiences potentially affect their academic choices and achievements in the following years (Leibham et al., 2013). Family support also helps them build up their economic future as adults improve their contributions (Raynal et al., 2021).

Several studies (e.g., Bell \& St. Clair, 2015; Eisenberg et al., 2010; Kurt \& Taş, 2019; Quiley et al., 2011) have found that providing an interest in science in early childhood strengthens children's learning of science content. For example, Fragkiadaki and Ravanis (2021) pointed out that a child's emotions in participating in, contributing to, or being in scientific activities or environments have a crucial role in examining and understanding children's early learning and development related to science. To achieve this situation, it is the duty of the family, the first social circle of the child, to support the child in science-related issues before starting school, where the learning of science content is carried out in a planned manner (Archer et al., 2012). If we hope to understand how children first learn to explore their surroundings, we need to investigate where they spend most of their time outside school (Keifert \& Stevens, 2019). We should also consider these extracurricular areas as affluent places for learning (Giles, 2021; Vossoughi \& Gutiérrez, 2014). That is why the family has a significant influence on children's development, interests and attitudes in all aspects. Many studies indicate a positive correlation between parents' attitudes children's attitudes on any issue (Fragkiadaki \& Ravanis, 2021; Goldman et al., 2021; Raynal et al., 2021). Therefore, early parental involvement and encouraging parental participation in later education are 
essential and should be encouraged for many reasons mentioned above (Kurt \& Taş, 2019).

\section{Parental Encouragement to Science Engagement}

The socio-cultural approach based on Vygotsky (1978) related how children learn through the interaction with parents and the environment. The theory has also emphasized that adults have an essential role in developing higher mental functions of children. Besides that, the socio-cultural theory has noted that cultural influences have a dimension of the learning process. Vygotsky's theory provides a valuable framework for understanding teaching interactions between child and parent. Specifically, these interactions show how the transition process is going from collaborative problemsolving to the child's independent operation. Through collaborative problem solving, children learn to define tasks, construct their knowledge and manage the situation through engaging participation in organized activities under the guidance of elders (Sun \& Moreno, 2020).

Parental education, family activities, and conversations between children and adults affect how children perceive and relate to science (Raynal et al., 2021). In addition, parents' attitudes, values, and practices towards science positively influence children's expectations and participation in science (Archer et al., 2012; DeWitt et al., 2013). However, supporting the children's interest in science and correctly guiding them can be complex. This complexity is not only related to the child and their interest but also involving the family. For instance, on the one hand, Appiah-Kubi and Amoako (2020) research are finding explained that the thought of parents to see their children's participation in their education as part of the education they are expected to give them motivates their participation. On the other hand, some parents see this participation as not enough. For example, Silander et al. (2018) research shows that parents often feel that their young children lack the confidence and knowledge they need to support science learning; however, almost half of US families do some science activity every day. While its role in providing the foundation for parents and children to engage in science has been noted in many studies, the power of parent-child involvement remains largely unexplored (Strickler-Eppard et al., 2019). Science education in families is quite different from science in school. The families' understanding of science may differ, depending on their motivations and the way they figure out the world. These differences may display how families discuss science and embody it on their terms (Goldman et al., 2021). Taking part in various home and community environments or collecting information about those environments can reveal children's science backgrounds, family cultures, and science perception of both children and families (González et al., 2005; Moll, 2014).

Science is a study that emphasizes critical and logical thinking, curiosity, and doubt (Ayvac1 et al., 2016; McComas, 2014). In order to provide the child with the habit of scientific thinking in early childhood, which is based on lifelong learning, it is necessary to support scientific process skills (Aksüt, 2019; NRC, 1996). On the other hand, children are curious about everything; exploration, discovery, and analysis are natural motives. These skills, which are part of the scientific process, are expected to provide children with the foundation in science, provided that there is a suitable environment and family support (Archer et al., 2012). When a suitable environment is 
presented to children at an early age, they become more interested in science, more open to research and discovery (Akman et al., 2003). According to Aktamış et al. (2008);

Families should help their children in using skills such as observing, noticing a change, recognizing samples, making models, exploration, experimenting, predicting, measuring and sharing information, and should use these skills in their everyday life, this is because these skills are of importance for developing a scientific understanding (p. 40).

In that perspective, this science is called "family science" (Goldman et al., 2021). It has extraordinary features that can primarily establish science bases for young children by stimulating curiosity, exploration, experimentation, and interpretation (Crowley et al., 2001). For example, Solis and Callanan (2016) argue that families with less experience in formal school settings encourage more joint meaning-making in science tasks with their children; and family science also enables inquiry and play in ways that school science cannot.

\section{Literature Review}

Several studies have been conducted within the scope of early childhood and science. These studies focused on children's perceptions of science and scientists' concepts or science process skills. For example, preschool children's conceptions of the scientist (Ayvac1 et al., 2016) and 6-year-olds' views on science (Güler \& Akman, 2006) were investigated. As a result of these studies, it was determined that preschool children define a scientist with concepts such as men, laboratory, glasses, apron, and laboratory materials. In addition, studies were conducted on the scientific process skills of children aged 6 (Akman et al., 2003), the impact of activities with family participation on children's scientific process skills (Ulutaş \& Kanak, 2018). As a result, it was concluded that the social environment impacts children's development of scientific skills.

As the closest social environment, the role of the family has been investigated in various studies related to children's learning in many senses. For example, several studies have investigated science conversations with children of foreign families residing in the United States (Tenenbaum \& Callanan, 2008), parent-child conversations on science (Tenenbaum \& Leaper, 2003), family behaviour in familiar science environments (Dierking \& Falk, 1994) and how families shape their children's relationship with science and their identity related to science (Archer et al., 2012; DeWitt et al., 2013). As a result, there was a significant link between family attitudes and interests and the child's approaches. For example, according to a comprehensive survey conducted by DeWitt et al. (2013), family stances towards science, science experiences in school, the self-concept of the students in a science course, and the enthusiasm of students in science were found to be mainly correlated with positive parental attitudes (describing $50.5 \%$ of the variance in student eagerness). However, in Turkey, the relationship between activities and family participation is often in preschool (Ulutaş \& Kanak, 2018). Besides, children's science process skills and the impact of families on students' attitudes towards science (Aktamış et al., 2008) were discussed. In common with other studies, it was determined that family approaches influence the child's approach to science and that family is a significant factor in the child's orientation. 
Research conducted on science and children revealed that concepts related to science in children begin to form at an early age and are associated with family, teacher, and environmental conditions. The role of some variables in the role of families in directing children to science has been examined and discussed in studies. These are the gender of the child (Šimunović \& Babarović, 2021), the economic status of the families (Goldman et al., 2021), the mother or father status of the parent who takes care of the child (Bucci Liddy et al., 2021), cultural perspectives (Sun \& Moreno, 2020), and families perceived related their roles to encourage their children (Caspi et al., 2020). For example; Parents with lower incomes and fewer on-screen role notification reports were higher. Calabrese Barton et al. (2001) revealed that dealing with the life sciences was separate from their thoughts on motherhood and family life.

Although studies in the field of science in early childhood address the role of families in science process skills, and some variables in the role of parents in directing children to science, these studies are limited in terms of content and number. Although the quality of family interactions is critical in promoting children's stimulation and involvement (Eccles, 2007), no scale measured what families did to expose their children to science. In this context, it is believed that the development of a reliable and valid measurement tool that can be used to determine the impact of the orientation of children to science in early childhood by their families will contribute to the literature. In this direction, the current study aims to develop a scale to determine families' level of exposing their children to science.

\section{Methodology}

\section{Research Design}

This research is basic research as it aims to develop a valid and reliable scale to determine families' level of exposing their children to science. Basic research studies aim to add new ones to existing knowledge and increase knowledge in the field (Fraenkel et al., 2011). Therefore, researchers who conduct basic research studies are interested in gaining new knowledge rather than investigating the efficacy of specific educational practices. This study tries to increase awareness of how families shape children's engagement with science and reveals which activities can be related to the scientific understanding in line with the research type.

\section{Participants}

The criterion sampling method was drawn on to determine the study group of the research. Drawing on criterion sampling, the people who will participate in the study must have children aged 0-8 years. In this context, the pilot applications of the developed scale were conducted in 2020-2021 with 505 participants with children between the ages of $0-8$ residing in various provinces of Turkey. 
Table 1

EFA Study Group Demographic Characteristics

\begin{tabular}{cccc}
\hline \multicolumn{2}{c}{ Characteristics of Participants } & Frequency & Total \\
\hline \multirow{2}{*}{ Gender } & Female & 286 & 324 \\
& Male & 38 & 324 \\
Age & $18-25$ & 2 & \\
& $26-30$ & 92 & 324 \\
& $31-39$ & 194 & \\
\hline \multirow{3}{*}{ Education Level } & Primary school & 36 & \\
& Secondary school & 22 & \\
& High School & 58 & \\
& Associate degree & 30 & 324 \\
& Bachelor's degree and above & 144 & \\
\hline \multirow{2}{*}{ Number of Children } & 1 & 84 & 182 \\
\hline
\end{tabular}

The study group consists of the first application group. The exploratory factor analysis (EFA) was performed with 324 people, and the second application group, in which confirmatory factor analysis (CFA), was performed with 181 people. The descriptive information of the participants is displayed in Tables 1 and 2. 20 individuals in the EFA group and 18 individuals in the CFA group were excluded from the study due to the end analysis.

Table 2

CFA Study Group Demographic Characteristics

\begin{tabular}{cccc}
\hline Characteristics of Participants & Frequency & Total \\
\hline \multirow{2}{*}{ Gender } & Female & 162 & 181 \\
& Male & 19 & 181 \\
Age & $18-25$ & 27 & \\
& $26-30$ & 61 & 181 \\
& $31-39$ & 76 & \\
\hline \multirow{2}{*}{ Level of Education } & Primary school & 18 & \\
& Secondary school & 5 & \\
& High School & 36 & 181 \\
& Associate degree & 37 & \\
\hline Number of Children & Bachelor's degree and above & 93 & \\
\hline
\end{tabular}




\section{Data Collection}

This study aimed to prepare a "Scale to Determine Families' Level of Orienting their Children to Science", and to this end, a literature review was carried out. In this field, all research, which was given in the introduction section, have been linked, which can be strong or weak, between parents' actions encouraging or orienting their children to science. Therefore, many items were written down, and possible correlations and similarities of them in line with these research findings or variables. The deduction method has used writing the scale items and choosing the items. During the decision to the items, when there were any indicators or items related to cultural background or specific family types, they were excluded to avoid a group-specific scale. According to the results obtained from the literature review theoretical framework, a scale of 25 items was developed, with a deductive method as explained above, considering what approaches can guide children to science. The items created were submitted to expert opinion. In the expert opinions, attention was paid to selecting experts, who have addressed science in their thesis or other studies, worked in the field of scale development and measurement evaluation, are interested in preschool education and continue to work on these issues actively. In addition, a language expert was consulted to review the items in the context of meaning and sentence order. Experts were asked to select one of the ratings of "Appropriate/Appropriate, but should be corrected/Not appropriate" for each item on the scale and write their recommendations on the item if they selected the "Appropriate, but should be corrected" option. In line with the expert opinions, the necessary modifications were made on the items, and the final version of the questionnaire was reduced to 20 items prior to application. Then, the questionnaire was applied to the first study group of 324 individuals. As a result of the EFA analysis, two items were removed from the scale, taking item loads and overlapping status into account.

\section{Data Analysis}

EFA was performed on the data using the SPSS 26.0 package programme. Then CFA was applied through the LISREL 8.8 package program by taking into account the factor structures determined. Following a detailed factor analysis to test whether the scale structure gives the same result in similar situations, the Cronbach's alpha coefficient was calculated for the scale internal consistency (Pallant, 2001). Finally, by calculating the item statistics, the situation of the items in the structure within the scale was tried to be revealed.

\section{Ethical Procedures}

Approval of the Ethics Committee was acquired from Kastamonu University Ethics Committee by Decision No:53 dated 25.12.2020.

\section{Results}

The findings gained within the study procedure are given under four headings: the findings for explanatory factor analysis, the findings for confirmatory factor analysis, scale reliability and item analysis. 


\section{Findings for Exploratory Factor Analysis (EFA)}

This study aimed to 'Determine Families' Level of Exposing their Children to Science", and a 5-point Likert type scale was developed for this purpose. First, the content validity was established for the scale developed. The content validity is based on expert opinions on the degree to which the items or questions in a test adequately represent the structure (Christensen et al., 2014; Yurdagül \& Bayrak, 2012). In this context, opinions were collected from 6 experts, who have addressed science in their thesis or other studies, worked in scale development and measurement evaluation, are interested in preschool education and continue to work on these issues actively. In addition, an opinion was taken from a language expert to analyse the items in terms of meaning and sentence order. The expert opinions obtained were found to be inconsistent with each other. In line with the opinions, recommended modifications were made to the items considered necessary by the researchers. At the next stage, the Kaiser-MeyerOlkin (KMO) test and Bartlett's Sphericity test was performed to determine the suitability of the scale for factor analysis. A KMO value greater than .50 and a significant Bartlett's test result indicate that the sample size is adequate for factor analysis and the desired level of correlation between the scale items (Tabachnick \& Fidell, 2007). Pallant (2001), on the other hand, proposed that the KMO value should be above .6. In this study, the Kaiser-Meyer-Olkin value was .866, and the Bartlett's Sphericity test was $.000(p<.05)$. The value ranges that obtained data were suitable for factor analysis. In addition, the correlation matrix has been put work on to determine the level of relationship between the scale items, and the correlation between the scale items was found to be at the desired level.

After deciding the fitness of the data set for factor analysis, eigenvalue scores and variance ratio tables were examined to determine the scale factor number. According to the Kaiser criterion, it is necessary to pay attention to factors with an eigenvalue 1 or higher (Pallant, 2001). Accordingly, looking at Table 3, only the first four factors received values above 1 , and these factors account for a total of $69.290 \%$ of the variance.

Table 3

Eigenvalue and Variance Results

\begin{tabular}{cccc}
\hline Factor & Eigenvalue & Variance $(\%)$ & Cumulative (\%) \\
\hline 1 & 7.837 & 39.184 & 39.184 \\
2 & 2.690 & 13.452 & 52.636 \\
3 & 1.375 & 6.876 & 64.768 \\
4 & 1.051 & 5.255 & 69.290 \\
\hline
\end{tabular}

Other methods used in determining the number of factors include Cattell's scree plot, Bartlett's test, Velicer's MAP test, and Horn's Parallel Analysis tests (Yavuz \& Doğan, 2015). Recent studies note that the number of dimensions should be determined according to MAP tests and Horn parallel analysis tests (Pallant, 2001; Yavuz \& Doğan, 2015). For this reason, Horn parallel analysis was applied to choose the number of factors to keep. Eigenvalues greater than the criterion values obtained in the parallel 
analysis are kept when deciding on the number of factors (Pallant, 2001). Table 4 shows a comparison of eigenvalue results and parallel analysis.

Table 4

Parallel Analysis and Comparison of Eigenvalue Results

\begin{tabular}{cccc}
\hline Factor No & Eigenvalue & Criterion Value & Conclusion \\
\hline 1 & 7.837 & 1.4831 & Keep \\
2 & 2.690 & 1.3918 & Keep \\
3 & 1.375 & 1.3253 & Keep \\
4 & 1.051 & 1.2644 & Remove \\
\hline
\end{tabular}

According to Table 4, three factors whose eigenvalues are more significant than the criterion value were obtained. These findings support the idea that the scale should consist of 3 factors. In this context, the scale was limited to 3 factors and re-analysed. As a consequence of the analysis, it was found that the three-factor structure explains $59.512 \%$ of the variance. In order to see how much of the variance each item on the scale explains, the table of commonalities for each item presented in Table 5 was examined.

Table 5

Variance Explained for Each Item (Communalities)

\begin{tabular}{|c|c|c|}
\hline Item No & Initial & Extraction \\
\hline i7 & 1.000 & .714 \\
\hline i3 & 1.000 & .361 \\
\hline i8 & 1.000 & .822 \\
\hline i9 & 1.000 & .775 \\
\hline i10 & 1.000 & .453 \\
\hline i16 & 1.000 & .656 \\
\hline i17 & 1.000 & .616 \\
\hline i19 & 1.000 & .672 \\
\hline i20 & 1.000 & .749 \\
\hline i24 & 1.000 & .682 \\
\hline i25 & 1.000 & .438 \\
\hline i6 & 1.000 & .586 \\
\hline i11 & 1.000 & .707 \\
\hline i12 & 1.000 & .736 \\
\hline i13 & 1.000 & .445 \\
\hline i14 & 1.000 & .610 \\
\hline i15 & 1.000 & .520 \\
\hline
\end{tabular}


Considering the sample size and the studies in the literature (e.g., Kline, 2005; Pallant, 2001; Tabachnick \& Fidell, 2007), the item load value in this study was determined to be at least .40. Therefore, when looking at Table 5, it seems that i3 has a low value (.361) according to this limit value. In addition, as shown in Table 6 obtained as a result of the rotation, this item did not load into any factors. For this reason, it was decided to remove $\mathrm{i} 3$ from the scale.

Considering the distribution of factor loads after rotation given in Table 6, the dimensions in which each item is grouped are seen. According to the factor structures, the $1^{\text {st }}$ factor was called "Practical Applications (Activities and Experiments)", $2^{\text {nd }}$ factor was called "Introduction to Science", and $3^{\text {rd }}$ factor was called "Building Scientific Foundations". After determining the number of factors that make up the Scale for Determining the Levels of Families Orienting Their Children to Science, reasonable and inclusive factor names were determined for each factor in line with the literature. It was seen that the first factor did not include the activities and experiments that families did with their children. It is similar to "family science" activities (Goldman et al., 2021), which are the activities that family members do together. This dimension was named "Introduction to Science" because the items in the 2nd factor included the concepts underlying science and research. When examined in the relevant literature, it is similar to the nature of science (Akerson et al., 2011), which deals with children's scientists and their characteristics. The third dimension is named "Building Scientific Foundations" because it is a section where families directly interact with their children with science and science content. Giles (2021) emphasized that using scientific journals and trips to science centres lay an essential foundation for raising children as science literate. When the factors and context were considered, the i25 did not comply with the first factor, removing it from the scale. After the changes and item removals made on the scale, the total variance explained by the 3-factor structure was $62.254 \%$. EFA results after rotation for each item are given in Table 6 . The total variance explained by the 3 -factor structure was $62.254 \%$ after the changes in the scale and item removal. The EFA results are provided in Table 6 after the rotation. 


\section{Table 6}

EFA Results for the Scale of Determining the Families' Level of Directing Their Children to Science After Rotation

\begin{tabular}{|c|c|c|c|c|c|c|}
\hline \multirow{3}{*}{$\begin{array}{l}\text { Item } \\
\text { No }\end{array}$} & \multirow[t]{3}{*}{ Items } & \multirow[t]{3}{*}{ Communality } & \multirow{3}{*}{$\begin{array}{l}\text { Item- } \\
\text { Scale } \\
\text { Cor. }\end{array}$} & \multicolumn{3}{|c|}{ Factor Loadings } \\
\hline & & & & 1 & 2 & 3 \\
\hline & & & & $\begin{array}{c}\text { Practical } \\
\text { Applications }\end{array}$ & $\begin{array}{l}\text { Introduction } \\
\text { to Science }\end{array}$ & $\begin{array}{c}\text { Building } \\
\text { Scientific } \\
\text { Foundations }\end{array}$ \\
\hline $\mathrm{i} 12$ & $\begin{array}{l}\text { I take my child to scientific } \\
\text { activity workshops. }\end{array}$ & .736 & .615 & .893 & & \\
\hline i11 & I take my child to science fairs. & .707 & .577 & .887 & & \\
\hline i6 & $\begin{array}{l}\text { I ask my child questions that } \\
\text { he/she can establish a cause- } \\
\text { and-effect relationship. }\end{array}$ & .586 & .604 & .725 & & \\
\hline $\mathrm{i} 14$ & $\begin{array}{l}\text { I give my child a chance to } \\
\text { study nature. }\end{array}$ & .610 & .488 & .707 & & \\
\hline i22 & $\begin{array}{l}\text { I observe the sky (Sun, moon, } \\
\text { stars) with my child. }\end{array}$ & .567 & .620 & .702 & & \\
\hline $\mathrm{i} 13$ & $\begin{array}{l}\text { I allow my child to study in } \\
\text { detail the technological tools at } \\
\text { home so that he/she can } \\
\text { understand complex systems. }\end{array}$ & .445 & .526 & .621 & & \\
\hline i23 & $\begin{array}{l}\text { I make daily forecasts about the } \\
\text { weather/seasons with my child. }\end{array}$ & .445 & .515 & .601 & & \\
\hline i21 & $\begin{array}{l}\text { I tell my child about the works } \\
\text { of scientists. }\end{array}$ & .450 & .452 & .573 & & \\
\hline $\mathrm{i} 15$ & $\begin{array}{l}\text { I encourage my child to } \\
\text { produce new things. }\end{array}$ & .520 & .552 & .569 & & \\
\hline i8 & $\begin{array}{l}\text { I do activities that enhance my } \\
\text { child's sense of research. }\end{array}$ & .822 & .533 & & .831 & \\
\hline i9 & $\begin{array}{l}\text { I do activities to develop my } \\
\text { child's sense of discovery. }\end{array}$ & .775 & .534 & & .808 & \\
\hline i7 & $\begin{array}{l}\text { I do simple experiments at } \\
\text { home with my child. }\end{array}$ & .714 & .458 & & .789 & \\
\hline i20 & I tell my child about scientists. & .749 & .698 & & & -.830 \\
\hline i24 & $\begin{array}{l}\text { I do activities where my child } \\
\text { can make comparisons. }\end{array}$ & .682 & .662 & & & -.786 \\
\hline i16 & $\begin{array}{l}\text { I buy my child science-themed } \\
\text { magazines. }\end{array}$ & .656 & .564 & & & -.745 \\
\hline
\end{tabular}




\section{Findings for Confirmatory Factor Analysis}

CFA results for the Scale to Determine Families' Level of Exposing their Children to Science are presented in Figure 1.

Figure 1

The CFA Model for the Scale

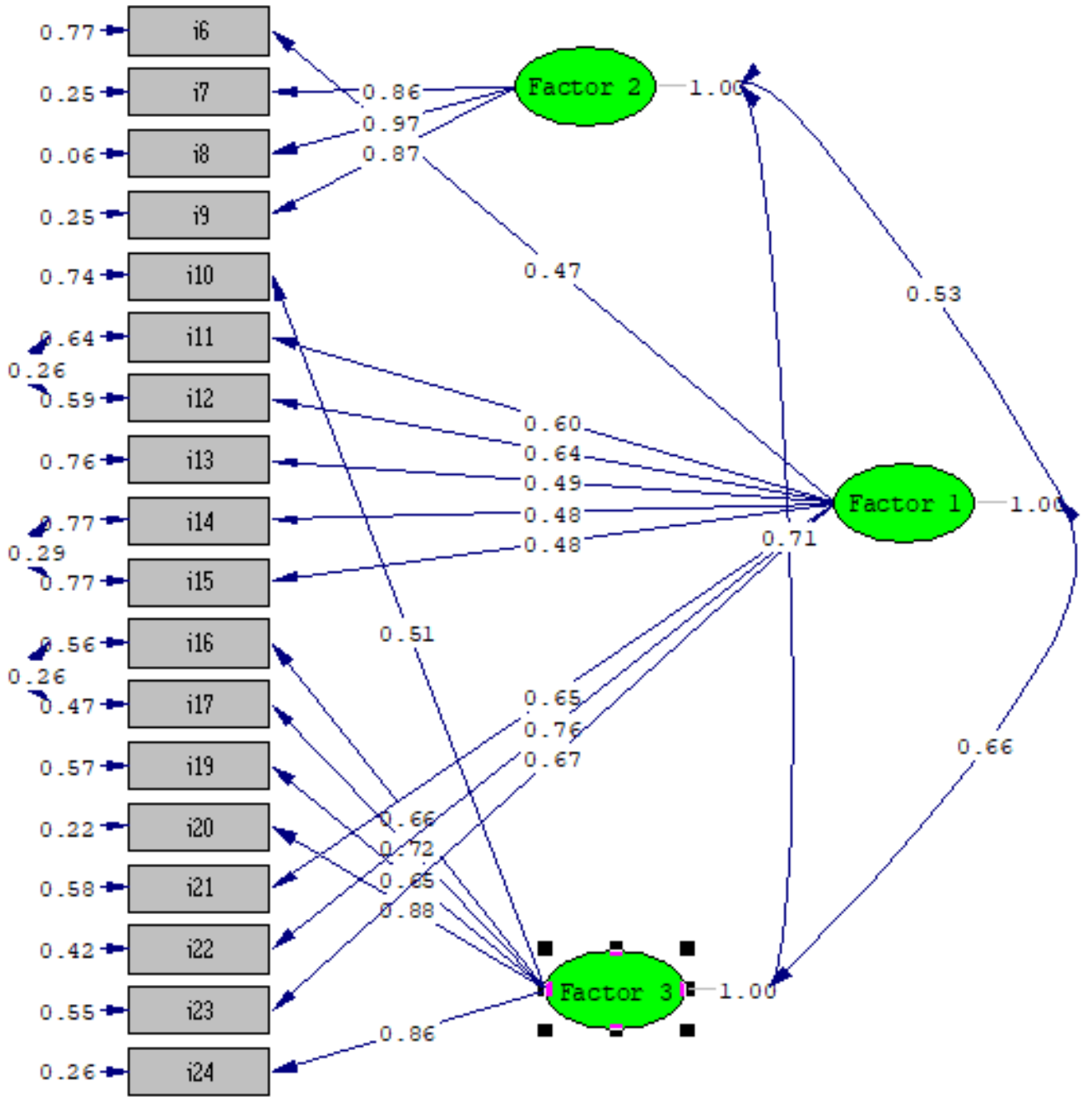

Chi-Square $=257.86, \mathrm{df}=129, \mathrm{P}$-value $=0.00000, \mathrm{RMSEA}=0.079$

The graph in Figure 1 shows the relations of items with factor loads and factors and the modifications made. The comparison results according to compliance indexes of this three-dimensional 18-item scale are given in Table 7. According to the results of the CFA, it was found that the $X^{2} / d f$ value was 2 , and the RMSEA value was .079. The decisions to accept the goodness of fits for CFA were made considering the criteria and limits listed by Schumacker and Lomax (2004). Besides, Kline (2005) stated that most preferred fit indices (CFI, AGFI, NFI, NNFI, IFI and GFI) should be $\geq .85$ to define as an acceptance. In line with these references, it was found that the values of NFI, RFI, CFI, GFI, RMR and RMSEA were above the acceptable limit value, while the values of NNFI, IFI and $X^{2} / d f$ were above the perfect fit limit. 
Table 7

Scale Analysis Values with Ranges of Acceptance of the Goodness of Fit Indices for $C F A^{*}$

\begin{tabular}{ccccc}
\hline $\begin{array}{c}\text { Fitness } \\
\text { Criterion }\end{array}$ & $\begin{array}{c}\text { Acceptable limit } \\
\text { (Good Fit) }\end{array}$ & Perfect fit limit & $\begin{array}{c}\text { Orientation to } \\
\text { Science Scale } \\
\text { Limit }\end{array}$ & Evaluation \\
NFI & $=.90$ and above & $=.95$ and above & .93 & Good fit \\
NNFI & $=.90$ and above & $=.95$ and above & .95 & Perfect Fit \\
IFI & $=.90$ and above & $=.95$ and above & .96 & Perfect Fit \\
RFI & $=.90$ and above & $=.95$ and above & .92 & Good Fit \\
CFI & $=.95$ and above & $=.97$ and above & .96 & Good Fit \\
GFI & $=.85$ and above & $=.90$ and above & .85 & Good Fit \\
RMR & $=.050$ and $=.080$ & $=.000$ and $<.050$ & .070 & Good Fit \\
RMSEA & $=.050$ and $=.080$ & $=.000$ and $<.050$ & .079 & Good Fit \\
$X^{2} / d f$ & 2 and $=3$ & $=0$ and $=2$ & 2 & Perfect Fit
\end{tabular}

* Schumacker and Lomax (2004)

When the scale results were examined in line with the data in Table 7 , it was determined that the values obtained from the scale were in the desired value range, and therefore, content validity was ensured.

\section{Scale Reliability}

We drew on Cronbach's alpha reliability coefficients to decide whether the scale has internal consistency or not, and it was found that as to be .91 for the current scale. In addition, reliability coefficient values of the sub-factors of the scale were also calculated. The analysis results of the reliability coefficient of the total scale and its subfactors were given in Table 8. This rate is considered quite good for a scale (Hinton et al., 2014).

Table 8

Reliability Coefficients of the Scale and its Sub-Factors

\begin{tabular}{lccc}
\hline \multicolumn{1}{c}{ Factors } & $\mathrm{N}$ & Items & Cronbach's Alpha \\
\hline $\begin{array}{l}\text { Practical Applications (Activities } \\
\text { and Experiment) }\end{array}$ & 9 & $6,11,12,13,14,15,21,22,23$ & .83 \\
Introduction to Science & 3 & $7,8,9$ & .92 \\
Building Scientific Foundation & 6 & $10,16,17,19,20,24$ & .88 \\
Total & 18 & & .91
\end{tabular}




\section{Item Analysis}

In the context of item analysis, the comparison of the $27 \%$ lower and upper groups formed in line with the item-total correlation and the total scores obtained from the scale was used in this study.

Item-total correlation is used to define the relationship between each scale item and the total score received from the scale. Besides, the average scores of groups formed in line with the total scores obtained from the scale from each item were compared with the independent sample t-test and are presented in Table 9.

Table 9

Item Analysis Results

\begin{tabular}{|c|c|c|c|}
\hline Factors & Items & $\begin{array}{l}\text { Corrected Item Total } \\
\text { Correlation }\end{array}$ & $\begin{array}{l}\text { Independent Group } \\
\text { T-Test for the } \\
\text { Comparison of } \\
\text { Upper } 27 \% \text { and } \\
\text { Lower } 27 \%\end{array}$ \\
\hline \multirow{9}{*}{$\begin{array}{c}\text { Practical Applications (Activities } \\
\text { and Experiments) }\end{array}$} & i6 & .35 & 5.32 \\
\hline & i11 & .56 & 9.50 \\
\hline & i12 & .52 & 7.34 \\
\hline & i13 & .49 & 6.90 \\
\hline & i14 & .34 & 4.50 \\
\hline & i15 & .43 & 6.55 \\
\hline & $\mathrm{i} 21$ & .54 & 8.62 \\
\hline & $\mathrm{i} 22$ & .58 & 8.17 \\
\hline & i23 & .60 & 9.42 \\
\hline \multirow{3}{*}{ Introduction to Science } & i7 & .64 & 9.88 \\
\hline & i8 & .72 & 12.99 \\
\hline & i9 & .74 & 12.92 \\
\hline \multirow{6}{*}{ Building Scientific Foundations } & i10 & .52 & 7.61 \\
\hline & i16 & .67 & 11.61 \\
\hline & i17 & .73 & 12.62 \\
\hline & i19 & .56 & 9.33 \\
\hline & $\mathrm{i} 20$ & .71 & 14.71 \\
\hline & i24 & .73 & 14.16 \\
\hline
\end{tabular}

According to Table 9, it is understood that the corrected item-total correlation value for the items in the "Determining the Levels of How Families Shape Children's Engagement with Science" scale is between .34 and 74. In addition, the lower and upper group independent sample t-test comparison of the scores obtained from each scale item was found to be significant $(p<.01)$. Accordingly, in each item of the scale, it is 
understood that the average score for each item of the upper $27 \%$ group is significantly higher than that of the lower $27 \%$ group. Therefore, since the item-total correlations are higher than .30 and the upper group subgroup t-test comparisons are significant (Tavşanc1l, 2002), it can be said that each item in the scale is valid and has high discrimination.

\section{Conclusion and Discussion}

In the current study, a scale was developed to determine the families' level of directing children to science. In this context, a 5-point Likert-type scale of 3 factors and 18 items was developed. The factors involved in the scale were called "Practical Applications (Activities and Experiments)", "Introduction to Science" and "Building Scientific Foundations". Following the expert opinions, five items have removed the scale, which was prepared as a 25-item scale at first; the explanatory factor analysis was performed with 20 items, and two items were removed from the scale due to the analysis. The "Practical Applications (Activities and Experiments)" factor was loaded more by the participants, and nine items were grouped under this heading. In addition, there were three items under the heading "Introduction to Science", and six items under the heading "Building Scientific Foundations".

In line with the literature, there are many studies of parental encouragement and motivation to children in a good deal of different senses. For example, some studies (e.g., Raynal et al., 2021) are interested in everyday activities performed by parents and children and define the effect of these activities on different variables. The first factor of this scale, "Practical applications", can enlighten these everyday activities shared by children and parents. It also supports which activities can connect with supporting meaning, as the widespread perception that science is compelling poses a significant barrier to caregivers who would otherwise involve children in learning (Calabrese Barton \& Yang, 2000). Goldman et al. (2021) has also defined these activities as a "family science". The second factor, "Introduction to Science", has also linked between nature of science (NOS) and families. Since the NOS studies are related to how science can be related to the production stage and fundamental values on the science (Kaya et al., 2016), it focused on how the families explain the meaning of the research, the sense of discovery, and the first simple experiments during early childhood. Akerson et al. (2011) also suggested that familiarity with the nature of science should be started early childhood. That is why the second factor can be defined as the first attempt of the families to introduce the nature of science. The third factor, "Building Scientific Foundations", has a particular version of family activities due to more like science aspect and containing science magazines and science centers. Many studies (e.g., Giles, 2021; Sawyer, 2005) explain that the crucial roles of science and technology centre on the potential for children's science literacy skills. For example, Sawyer (2005) stated that science literacy learning begins at birth, and the families knowing and unknowingly affect the quality of the happens across multiple settings. The importance of these roles orienting to the scientific perspective third factor has become more important to shape children' understanding of science.

Opinions were obtained from seven experts on the scale's content validity, linguistic validity, and meaning characteristics. Given the expert opinion, five items that do not serve the desired purpose were removed from the scale. In the study, the KMO 
value of the scale was found to be .866. An increase in KMO value indicates that each variable on the scale has high predictability by other variables and is suitable for factor analysis (Keçe et al., 2020). EFA, Parallel Analysis and CFA were performed to determine the factors. Therefore, it can be stated that the scale is valid, considering the rates of variance explained, eigenvalues and factor loads of the items. Scale items need to explain at least $40 \%$ of the total variance in a scale development study, and factor loads need to be greater than .30 (Pallant, 2001).

CFA was performed to verify the data grouped under three factors, as found by EFA. It was determined that the construct validity of the scale was confirmed, and the factor structure was verified. Therefore, it can be stated that the items on the scale and the factors under which they are collected can measure the feature that needs to be measured within the scope of the scale (Keçe et al., 2020). We drew on Cronbach's alpha reliability coefficients to decide whether the scale has internal consistency or not, and it was found that as to be .91 for the current scale. It can be stated that this developed scale has an excellent internal consistency coefficient. This is because a reliability coefficient value of .70 and above for a scale indicates that the results obtained from the scale are reliable (Can, 2014). In line with the results, the scale will play an essential role in revealing the role of families, especially in increasing children's interest in science and science-related fields. According to studies conducted so far (e.g., Aydeniz, 2017), increasing students' interest in science and science-related fields has a vital role in STEM fields and gaining 21st-century skills. Similarly, the NRC (2011) report recommends that studies should be carried out to increase children's interest in science at an early age. In light of the points highlighted in this report, it is thought that the obtained scale can fill an essential gap in the field, especially in Turkey.

According to all analyses and reviews conducted on the scale, a scale was prepared that can be applied to each parent and determine the level of children's orientation to science. With the scale developed, researchers can collect information from parents of all ages and levels of education about their children's orientation to science and support their research with qualitative data. It is thought that this scale will be helpful, especially for researchers who want to investigate children's perception of young children's science, the roles of parents, and the effects of their actions on this perception. In addition, it is thought that educators and policymakers can use the data obtained from this scale to determine family roles to be encouraged towards science or to decide what families can do to improve children's understanding of science. In both cases, it can be said that it is a scale that will benefit both the field and practitioners with its essential contributions.

\section{Limitations}

This scale was developed to determine what families do to orient their children to science. The scale does not examine the reasons behind families taking these actions. There are studies in the literature that there may be sub-reasons such as academic success, career development, high income or career choice among these reasons. However, since these justifications cannot be obtained with this scale, it can be said that this is a limitation for this scale. It is thought that qualitative data other than quantitative data are needed to determine these reasons. Apart from this, items with cultural elements or specific family characteristics were not selected during item selection for 
the scale. Because it was not preferred to limit the scale to a certain culture or family group. If desired, demographic characteristics can be collected together with the scale, and data can be compared, or inferences can be made for the mentioned items. Researchers or practitioners who will use the scale should consider these limitations.

\section{Statement of Responsibility}

Emine Bal; Planning and implementation of scale development study, methodology, literature review, formal arrangement, verification, reporting, writing reviewing and inspection. Gökhan Kaya; Determination of problem situation, determination of sample group, planning and implementation of scale development study, analysis, verification, analysis.

\section{Conflicts of Interest}

This research has no financial, commercial, legal or professional relationship with other organizations or those working with them. There is no conflict of interest that would affect the research.

\section{Author Bios:}

Emine Bal holds a bachelor's degree in Early Childhood Education from Kastamonu University. She continues her own postgraduate education in the Master program at Early Childhood Education. Her research focuses on science engagement in the early childhood period.

Gökhan Kaya holds a Master of Arts and Ph.D. degrees in Science Education from Hacettepe University. He earned a Doctoral Research Fellowship to carry out his research at Newcastle University School of Education, Communication and Language Sciences in 2014-2015. He is an Assistant Professor of Early Childhood Education at Kastamonu University. His research interest focusses on classroom interaction among students and between teacher-student, and classroom discourse in the science classroom. $\mathrm{He}$ has been worked as a researcher in many European Projects which was related to classroom discourse and teacher education. He is a member of Multimodal Analysis Research Group (MARG) in Newcastle University and Hacettepe University MicroAnalysis Network Research Center. 


\section{References}

Akerson, V. L., Buck, G. A., Donnelly, L. A., Nargund, V., \& Weiland, I. S. (2011). The importance of teaching and learning nature of science in the early childhood years. The Journal of Science Education and Technology, 20, 537-549. https://doi.org/10.1007/s10956-011-9312-5.

Akman, B., Üstün, E., \& Güler, T. (2003). Using science process skills in 6 years old children. Hacettepe University Journal of Education, 24, 11-14.

Aksüt, P. (2019). Erken çocukluk döneminde fen eğitimi nedir? [What is science education in early childhood?] In Pelin A. (Ed.), Erken çocukluk döneminde fen eğitimi [Science education in early childhood] (pp. 1-22). Nobel Academic Publishing.

Aktamış, H., Ünal, G., \& Ergin, Ö. (2008). Öğrencilerin fene yönelik tutumlarına ailelerin etkisi [Students' attitudes towards science influence of their families]. Aile ve Toplum, 14(4), 39-48.

Appiah-Kubi, J., \& Amoako, E. O. (2020). Parental participation in children's education: Experiences of parents and teachers in Ghana. Kuramsal Eğitimbilim Dergisi [Journal of Theoretical Educational Science], 13(3), 456-473. http://dx.doi.org/10.30831/akukeg.634484

Archer, L., DeWitt, J., Osborne, J., Dillon, J., Willis, B., \& Wong, B. (2012). Science aspirations, capital, and family habitus: How families shape children's engagement and identification with science. American Education Research Journal, 49(5), 881908. https://doi.org/10.3102/0002831211433290

Aydeniz, M. (2017). Ĕ̈itim sistemimiz ve 21. yüzyll hayalimiz: 2045 hedeflerine ilerlerken, Türkiye için STEM odakl ekonomik bir yol haritası [Our education system and our 21st-century dream: A STEM-focused economic roadmap for Turkey as we move towards 2045 goals]. University of Tennessee.

Ayvac1, H. Ş., Atik, A., \& Ürey, M. (2016). The perceptions of preschool children on the concept of scientist. Bartin University Journal of Faculty of Education, 5(3), 669-689. https://doi.org/10.14686/buefad.v5i3.5000193186

Bell, R. L., \& St. Clair, T. L. (2015). Too little too late: Addressing nature of science in early education. In M. C. Trundle \& M. Sackes (Eds.), Research in early childhood science education (pp. 125-141). Springer.

Bucci Liddy, C. M., Brumariu, L. E., Diaconu-Gherasim, L. R., \& Hunter, D. M. (2021). Maternal parenting and teaching strategies: relations with children's academic competence. Educational Studies, https://doi.org/10.1080/03055698.2021.1940870

Calabrese Barton, A., Hindin, T. J., Contento, I. R., Trudeau, M., Yang, K., Hagiwara, S., \& Koch, P. D. (2001). Underprivileged urban mothers' perspectives on science. Journal of Research in Science Teaching, 38(6), 688-711. https://doi.org/10.1002/tea.1026

Calabrese Barton, A., \& Yang, K. (2000). The culture of power and science education: Learning from Miguel. Journal of Research in Science Teaching, 37(8), 871-889. https://doi.org/10.1002/1098-2736(200010)37:8<871::AID-TEA7>3.0.CO;2-9 
Can, A. (2014). SPSS ile bilimsel araştırma sürecinde nicel veri analizi [Quantitative data analysis in the scientific research process with SPSS]. Pegem A Publishing.

Caspi, A., Gorsky, P., Nitzani-Hendel, R., Zacharia, Z. C., Rosenfeld, S., \& Shildhouse, B. (2020). Children's perceptions of the factors that led to their enrolment in advanced, middle-school science programmes. International Journal of Science Education, 42(11), 1915-1939. https://doi.org/10.1080/09500693.2020.1802083

Christensen, L., Johnson, R., \& Turner, L. (2014). Research methods, design, and analysis. Pearson.

Crowley, K., Callanan, M. A., Jipson, J. L., Galco, J., Topping, K., \& Shrager, J. (2001). Shared scientific thinking in everyday parent-child activity. Science Education, 85, 712-732. https://doi.org/10.1002/sce.1035

DeWitt, J., Osborne, J., Archer, L., Dillon, J., Willis, B., \& Wong, B. (2013). Young children's aspirations in science: The unequivocal, the uncertain and the unthinkable. International Journal of Science Education, 35(6), 1037-1063. https://doi.org/10.1080/09500693.2011.608197

Dierking, L. D., \& Falk, J. H. (1994). Family behavior and learning in informal science settings: A review of the research. Science Education, 78(1), 57-72.

Eccles, J. S. (2007). Families, schools, and developing achievement-related motivations and engagement. In J. E. Grusec \& P. D. Hastings (Eds.), Handbook of socialization (pp. 665-691). The Guilford Press.

Eisenberg, N., Vidmar, M., Spinrad, T. L., Eggum, N. D., Edwards, A., Gaertner, B., \& Kupfer, A. (2010). Mothers' teaching strategies and children's effortful control: A longitudinal study. Developmental Psychology, 46(5), 1294-1308. https://doi.org/10.1037/a0020236

Fraenkel, J. R., Wallen, N. E., \& Huyn, H. H. (2011). How to design and evaluate research in education. MacGraw-Hill.

Fragkiadaki, G., \& Ravanis, K. (2021). The unity between intellect, affect, and action in a child's learning and development in science. Learning, Culture and Social Interaction, 29. https://doi.org/10.1016/j.lcsi.2021.100495

Giles, R. M. (2021). Science, technology, and literacy? Assessing the potential for children's reading and writing in four science centres, International Journal of Early Years Education, $\quad 29(1), \quad 88-95$. https://doi.org/10.1080/09669760.2020.1759400

Goldman, S., Luce, M. R., \& Vea, T. (2021). Opportunities and tensions in family science: challenging dominant paradigms of science education. Cultural Studies of Science Education, 16, 621-641. https://doi.org/10.1007/s11422-020-09998-0

González, N., Moll, L. C., \& Amanti, C. (2005). Funds of knowledge: Theorizing practices in households, communities, and classrooms. Routledge.

Güler, T., \& Akman, B. (2006). 6 year old children's views on science and scientists. Hacettepe University Journal of Education, 31, 55-66.

Hinton, P. R., McMurray, I., \& Brownlow, C. (2014). SPSS explained. Routledge.

Kaya, G., Şardağ, M., Cakmakci, G. Doğan, N., İrez, S., \& Yalaki, Y. (2016). Discourse patterns and communicative approaches for teaching nature of science. Education and Science, 41(185), 83-99. https://doi.org/10.15390/EB.2016.4852 
Keçe, B., Saraçoğlu, S., \& Bektaş, O. (2020). Developing a scientific attitude scale: Validity and reliability study. MM-International Journal of Educational Sciences, 4(2), 32-56. https://doi.org/10.46762/mamulebd.774267

Kefi, S., Çeliköz, N., \& Erişen, Y. (2013). Preschool teachers' levels of using the basic science process skills. Journal of Research in Education and Teaching, 2(2), 300319.

Keifert, D., \& Stevens, R. (2019). Inquiry as a members' phenomenon: Young children as competent inquirers. Journal of the Learning Sciences, 28(2), 240-278. https://doi.org/10.1080/10508406.2018.1528448.

Kline, R. B. (2005). Principles and practice of structural equation modeling (2nd ed.). Guilford.

Kunt, B. (2015). The Preschool student's determination of science process skills (60 72 months) [Unpublished master's thesis] Dumlupınar University, Institute of Education Sciences.

Kurt, U., \& Taş, Y. (2019). Prediction of students' strategies for doing science homework by parental support and students' goal orientation. Pegem Eğitim ve Öğretim Dergisi, 9(2), 585-604, http://dx.doi.org/10.14527/pegegog.2019.019.

Leibham, M. B., Alexander, J. M., \& Johnson, K. E. (2013). Science interests in preschool boys and girls. Science Education, 97(4), 574-593. https://doi.org/10.1002/sce.21066.

McComas, W. F. (2014). Science process skills. In McComas W.F. (Ed.), The language of science education. Sense Publishers

Moll, L. C. (2014). L. S. Vygotsky and education. Routledge.

Morgan, P. L., Farkas, G., Hillemeier, M. M., \& Maczuga, S. (2016). Science achievement gaps begin very early, persist, and are largely explained by modifiable factors. Educational Researcher, 45(1), 18-35. https://doi.org/10.3102/0013189X16 633182.

National Research Council [NRC]. (1996). National science education standards. National Academy of Sciences.

National Research Council [NRC]. (2007). Taking science to school: Learning and teaching science in grades $k-8$. National Academies Press. https://doi.org/10.17226/11625.

National Research Council [NRC]. (2011). Successful K-12 science education: identifying effective approaches in science, technology, engineering and mathematics. The National Academic Press.

National Research Council [NRC]. (2012). A framework for K-12 science education: Practices, crosscutting concepts, and core ideas. National Academies Press. https://doi.org/10.17226/13165.

Pallant, J. (2001). SPSS survival manual. Open University Press.

Quiley, C., Buck, G., \& Akerson, V. (2011). The NOS challenge. Science and Children, 49, 57-61.

Raynal, A., Lavigne, H., Goldstein, M., \& Gutierrez, J. (2021). Starting with parents: Investigating a multi-generational, media-enhanced approach to support informal 
science learning for young children. Early Childhood Education Journal. https://doi.org/10.1007/s10643-021-01209-x

Sawyer, R. K. (2005). The Cambridge handbook of the learning sciences. Cambridge University Press.

Silander, M., Grindal, T., Hupert, N., Garcia, E., Anderson, K., Vahey, P., \& Pasnik, S. (2018). What parents talk about when they talk about learning: a national survey about young children and science. Education Development Center.

Schumacker, R. E., \& Lomax, R. G. (2004). A beginner's guide to structural equation modeling. Lawrence Erlbaum Associates.

Šimunović, M., \& Babarović, T. (2021). The role of parental socializing behaviors in two domains of student STEM career interest. Research in Science Education, 51, 1055-1071. https://doi.org/10.1007/s11165-020-09938-6

Solis, G., \& Callanan, M. (2016). Evidence against deficit accounts: Conversations about science in Mexican heritage families living in the United States. Mind, Culture, and Activity, 23(3), 212-224. https://doi.org/10.1080/10749039.2016.1196493

Strickler-Eppard, L., Czerniak, C. M., \& Kaderavek, J. (2019). Families' capacity to engage in science inquiry at home through structured activities. Early Childhood Education Journal, 47(6), 653-664. https://doi.org/10.1007/s10643-019-00958-0

Sun, K., \& Moreno, R. P. (2020). Chinese Mother-Child Interactions in Everyday Math Activities: Engaging Young Children in Mathematics at Home. Early Childhood Education Journal, 49, 1061-1072. https://doi.org/10.1007/s10643-020-01118-5

Tabachnick, B. G., \& Fidell, L. S. (2007). Using multivariate statistics (5th ed.). Allyn \& Bacon.

Tavşancıl, E. (2002). Tutumların ölçülmesi ve SPSS ile veri analizi. Nobel Yayıncılık.

Tenenbaum, H. R., \& Callanan, M. A. (2008). Parents' science talk to their children in Mexican-descent families residing in the USA. International Journal of Behavioral Development, 32(1), 1-12. https://doi.org/10.1177/0165025407084046

Tenenbaum, H. R., \& Leaper, C. (2003). Parent-child conversations about science: Socialization of gender inequities. Developmental Psychology, 39(1), 34-47. https://doi.org/10.1037//0012-1649.39.1.34

Ulutaş, A., \& Kanak, M. (2018). Effect of the cooperative learning with family involvement based science education on the scientific process skills of 5-6-year-old children. NeuroQuantology, $\quad$ 16(11), 20-29. https://doi.org/10.14704/nq.2018.16.11.1263

Vossoughi, S., \& Gutiérrez, K. D. (2014). Studying movement, hybridity, and change: Toward a multi-sited sensibility for research on learning across contexts and borders. Teachers College Record, 116(14), 603-632. https://doi.org/10.1177/016146811411601413

Vygotsky, L. S. (1978). Mind in society: The development of higher psychological processes (M. Cole, V. John-Steiner, S. Scribner, \& E. Souberman, Eds.). Harvard University Press. 
Yavuz, G., \& Doğan, N. (2015). Using velicer's map test and horn's parallel analysis for determining component number. Hacettepe University Journal of Education, 30(3), 176-188.

Yurdagül, H., \& Bayrak, F. (2012). Content validity measures in scale development studies: Comparison of content validity index and kappa statics. Hacettepe University Journal of Education, Special Issue 2, 264-271. 